\title{
Changes in the Sleep Quality and Physical Activity Habits of Vocational School Students During the Covid-19
}

\author{
Covid-19 Pandemi Sürecinde Sağlık Hızmetleri Meslek Yüksekokulu Öğrencilerinin Uyku \\ Kalitesi ve Fiziksel Aktivite Alışkanlıklarındaki Değiş̧iklikler
}

\author{
Orkide PALABIYIK ${ }^{1}$ (D), Nurcan ERDOGAN KURTARAN' (D), Selcuk KORKMAZ ${ }^{2}$ (D)
}

\begin{abstract}
Aims: Due to the COVID-19 pandemic, a decision to implement distance education became effective in Turkey as of March 22, 2020. The present study aims to investigate the changes in the sleep quality and physical activity habits of university students during distance education.

Material and Methods: A total of 634 students from Trakya University Health Services Vocational School, consisting of 463 females and 171 males, participated in the study. The Pittsburgh Sleep Quality Index (PSQI) and the International Physical Activity Short Form (IPAQ-SF) were applied online to evaluate the sleep quality, physical activity levels and sedentary behavior of the participants.

Results: A significant increase was observed in PSQI scores under the restrictions introduced during the COVID-19 pandemic compared to the pre-pandemic period $(\mathrm{p}<0.001)$. Subjective sleep quality score was found to be higher in females than in males $(p<0.001)$. However, a significant decrease in IPAQ-SF scores was noted in both genders during the COVID-19 pandemic compared to before the pandemic $(\mathrm{p}<0.001)$. Mean daily sitting time was found to increase from $7.5(4.5-10.5)$ hours before the pandemic to 12 (7.5-16.5) hours during the pandemic.

Conclusion: Students' sleep quality and physical activity habits were negatively affected during the COVID-19 pandemic. In this regard, awareness-raising activities and training should be organized and implemented to improve sleep quality, increase
\end{abstract}

Orkide PALABIYIK (四)

Trakya University Health Services Vocational College, Electronorophysiology Program, Balkan Campus 22030 Edirne TURKEY.

e-mail: orkide_69@hotmail.com

${ }^{1}$ Trakya University Health Services Vocational College, Electronorophysiology Program. and Doctoral student.

${ }^{2}$ Trakya University Faculty of Medicine, Biostatistics and Medical Informatics Department and Associate professor. physical activity and reduce sedentary behavior in students during the repeated lockdowns. Furthermore, the use of mobile applications with social networking features or wearable technologies that support this purpose may help raise awareness and increase motivation for physical activity.

Keywords: COVID-19, IPAQ-SF, PSQI, physical activity, sleep, sedentary living.

\section{ÖZ}

Amaç: COVID-19 salgını nedeniyle, 22 Mart 2020 itibariyle Türkiye'de uzaktan eğitim uygulama kararı yürürlüğe girdi. Bu çalışma, uzaktan eğitim sırasında üniversite öğrencilerinin uyku kalitesi ve fiziksel aktivite alışkanlıklarındaki değişiklikleri incelemeyi amaçlamaktadır.

Gereç ve Yöntemler: Çalışmaya Trakya Üniversitesi Sağlık Hizmetleri Meslek Yüksekokulu'ndan 463 kı ve 171 erkek olmak üzere toplam 634 öğrenci katıldı. Katılımcıların uyku kalitesi, fiziksel aktivite düzeyleri ve hareketsiz davranışlarını değerlendirmek için Pittsburgh Uyku Kalitesi İndeksi (PSQI) ve Uluslararası Fiziksel Aktivite Kısa Formu (IPAQ-SF) çevrimiçi olarak uyguland.

Bulgular: COVID-19 pandemisi sirasında getirilen kısıtlamalar kapsamında PSQI skorlarında pandemi öncesi döneme göre anlamlı artış gözlendi $(\mathrm{p}<0,001)$. Öznel uyku kalitesi puanı kadınlarda erkeklere göre daha yüksek bulundu ( $p<0,001)$. Bununla birlikte, COVID-19 pandemisi sırasında her iki cinsiyette de pandemi öncesine kıyasla IPAQ-SF puanlarında anlamlı bir düşüş kaydedildi $(\mathrm{p}<0.001)$. Ortalama günlük oturma süresinin pandemiden önceki 7,5 (4,5-10,5) saatten pandemi sırasında 12 (7,5-16,5) saate yükseldiği görüldü.

Sonuç: COVID 19 salgını sürecinde öğrencilerin uyku kalitesi ve fiziksel aktivite alışkanlıkları olumsuz etkilendi. Bu bağlamda, öğrencilerde uyku kalitesinin iyileştirilmesi, fiziksel aktivitenin artırılması ve tekrarlanan kısıtlamalar sırasında hareketsizlik davranışının azaltılması için farkındalık artırıcı faaliyetler ve eğitimler düzenlenmeli ve uygulanmalıdır. $\mathrm{Bu}$ amacı destekleyen sosyal ağ özellikleri veya giyilebilir teknolojilere sahip mobil 
uygulamaların kullanılması, fiziksel aktivite için farkındalığın ve motivasyonun artmasına yardımcı olabilir.

Anahtar Kelimeler: COVID-19, IPAQ-SF, PSQI, fiziksel aktivite, uyku, hareketsiz yaşam.

\section{INTRODUCTION}

Coronavirus Disease 19 (COVID-19) pandemic is currently a major global health issue. The World Health Organization (WHO) declared COVID-19 a pandemic on March 11, 2020 (1). The rapid spread of the pandemic, threatening all countries affected and the global economy, led to various measures and practices across the globe. Similar actions have been taken in Turkey in order to minimize the spread of the COVID-19 outbreak. With the decisions taken on March 22, 2020, a lockdown until June 25,2020 has been imposed on individuals aged 65 years or above and those under the age of 20 years.

Following healthcare services, education is one of the fields most affected by the pandemic. The Presidency of the Council of Higher Education announced new decisions to ensure that education and training processes continue in universities without interruption as much as possible given the circumstances. As a result of these decisions, a compulsory break in education came into effect, during which distance learning was initiated for theoretical courses from March 26, 2020 to the end of the spring semester.

Distance education was started for the same period at Trakya University Health Services Vocational School. During the period when the aforementioned lockdown was in effect and voluntary quarantine was encouraged, a significant change may occur in the sleep timing and duration as the time spent on online platforms increased quantitatively among distance education students. When the negative effects of social isolation in young adults are examined, it is seen that this effect leads to a decrease in physical activity and unhealthy eating habits $(2,3)$. Such a situation also results in reduced exposure to natural light and an increased exposure to artificial lighting. This may alter an individual's intrinsic rhythm, disrupting interrelated aspects such as appetite, mood, energy levels, and sleeping hours (4, 5 ). Good sleep quality and adequate sleep duration improve quality of life by increasing the physical performance of an individual as well as the mental performance, such as attention, perception and learning $(6,7)$. Insufficient sleep or sleep that is sufficient in duration but of poor quality causes daytime sleepiness, slow perception and increased levels of distraction (8). Daytime sleepiness may have an unfavorable effect on academic success and performance in students (9).

Physical activity is defined as all bodily movements (routine daily activities such as housework, shopping, etc.) that result in energy expenditure (10-12). Curfews and strict measures taken in order to control the spread of the pandemic continue to be applied meticulously, despite the resulting decrease in physical activity levels of students, the associated inactive state in terms of daily routine and the increasing risk factors for non-communicable diseases.

In this study, we aimed to investigate the changes in the sleep quality and physical activity habits of students from Trakya University Health Services Vocational School, which switched to distance education in line with the strict measures introduced in Turkey in order to control the COVID-19 pandemic.

\section{MATERIAL AND METHODS}

The population of the study consisted of 1400 registered students. A total of 634 university students (463 female, 171 male) aged $18-35$ years (20.2 \pm 1.88 years) participated in this study. All participants were students of Trakya University Health Services Vocational School living in Turkey. All participants were assured confidentiality. The students whose responses were evaluated filled in the form completely. Individuals with orthopedic or neurological conditions interfering with physical activity and those with congenital musculoskeletal deformities were excluded from the study.

Study Design: This descriptive, cross-sectional study was conducted between 01 June 2020 and 20 June 2020 when a lockdown was in effect. Trakya University granted ethics approval for the study (TUTF-BAEK 2020/209). At the beginning of the survey, participants were asked whether they had voluntary consent. Participants who did not give voluntary consent could not proceed to the steps with other questions in the questionnaire. The design was created in such a way that all questions must be answered in the questionnaire. The questionnaire was distributed to the participants via Whatsapp groups. Only one answer was accepted from each student. All participants were informed about the study and provided their informed consent prior to participation. An online questionnaire survey was conducted among students from Trakya University Health Services Vocational School. All participants were informed about the study and informed consent was obtained. The Pittsburgh 
Sleep Quality Index (PSQI) and the International Physical Activity Short Form (IPAQ-SF) were applied online to evaluate the sleep quality, physical activity levels, and sedentary behavior of all participants. Both questionnaires were completed twice, including assessments before and during the COVID-19 pandemic.

\section{Measures}

Demographics Form And Other Questions: Participants' age, gender, educational status, height, and weight were evaluated with the form created by the researchers.

Anxiety levels related to COVID-19 were questioned between 0-10 points (0: Anxiety level did not change compared to before, 10: Anxiety level increased a lot).

Psychological impacts related to covid-19 also inquired with Likert type scale (none,..., too much)

Sleep quality: The Pittsburgh sleep quality index (PSQI) was used to assess sleep quality (13). The Turkish validity and reliability study of PSQI was performed by Ağargün et al. Cronbach's alpha internal consistency coefficient was found to be 0.80 (14). The study assessed the quality of sleep across seven subscales over the past month: subjective sleep quality, sleep latency, sleep duration, habitual sleep efficiency, sleep disturbances, use of sleep medication, and daytime drowsiness. Options for answers range from good to bad, with scores from 0 to 3 . PSQI uses a cut-off score of 5 points for the different categories of sleep quality. The sum of the scores based on the answers to the components in the questionnaire produces results in the range of 0-24 points (0-5 points: healthy sleep, 6-10 points: poor sleep, $>10$ : severe sleep problem). People with a score above 10 are considered to have advanced sleep problems. Cronbach's alpha statistics for during COVID 19 and before COVID 19 PSQI scales were 0.88 and 0.83 respectively.

Physical activity levels: The International Physical Activity Questionnaire Short Form (IPAQ-SF) was used to assess physical activity strength, including vigorous activity, moderate activity and walking, as well as daily sitting time. IPAQ-SF consists of seven self-reported questions, requiring a memory of physical activity in the past week. The questionnaire is used to determine the physical activity levels of adults aged 15-69 years. IPAQ-SF applies a criterion that a given physical activity is performed for no less than 10 minutes at a time. Physical activity is assessed in 4 intensity levels: a) vigorous physical activity, b) moderate physical activity, c) walking and d) sitting. In addition, participants were asked whether there was a change in body weight during the COVID 19 process. A score is obtained by multiplying the minute, day, and metabolic equivalent (MET) unit value. The calculation in the study was as follows: 8 METs for vigorous physical activity, 4 METs for moderate activity and 3.3 MET for walking. Physical activity levels were classified as physically inactive $(<600$ MET-min/week), low physical activity (600-3000 METmin/week), and adequate physical activity (>3000 METmin/week) (15). Cronbach's alpha statistics for last seven days and before COVID 19 IPAQ-SF scales were 0.70 and 0.65 respectively.

Statistical analysis: The Shapiro-Wilk's test was used to check normality assumption. For two independent groups; Student's t test was used for normally distributed numerical variables, whereas Mann-Whitney $U$ test was used for non-normally distributed numerical variables. For two dependent groups; paired samples t test was used for normally distributed numerical variables, whereas Wilcoxon test was used for non-normally distributed numerical variables. Descriptive statistics were expressed as mean and standard deviation for normally distributed numerical variables, and median and 25 th-75th percentiles for non-normally distributed numerical variables. A p value less than 0.05 considered as statistically significant. All statistical analyses were conducted using $\mathrm{R}$ software version 4-0.3 and TURCOSA (Turcosa Analytics Ltd. Co, www.turcosa.com.tr) statistical software.

\section{RESULTS}

Demographic data: A total of 634 participants (463 female, 171 male, mean age $=20.2 \pm 1.88$ years) were summarized in Table 1. The incidence of chronic disease was found to be higher in female than boys $(\mathrm{p}=0.015)$.

Evaluation of Sleep Quality: The PSQI results and its components were summarized in Table 2. The PSQI results before and during COVID-19 suggested that the sleep quality of the students deteriorated during the pandemic (before COVID-19: 5.02 \pm 2.45 vs during COVID-19: $6.48 \pm 3.04, \mathrm{p}<0.001$, figure $1-\mathrm{A})$. Similar deteriorations observed for subjective sleep quality, sleep latency, sleep disturbance and daytime dysfunction COVID-19 pandemic. Furthermore, sleep duration and sleep efficiency scores significantly decreased during COVID-19. Although there was a slight increase in the use of sleep medication during COVID-19, the difference was not significant compared 
to before COVID-19. Overall PSQI score found to be significantly higher in females compared to males during the COVID-19 pandemic ( $\mathrm{p}<0.001$, figure 1-B). Subjective sleep quality score found to be significantly higher in females compared to males during COVID-19 $(\mathrm{p}<0.001)$. However, no significant difference found between gender groups in terms of subjective sleep quality score before COVID-19 pandemic. On the other hand, subjective sleep quality score significantly increased during the COVID-19 pandemic in females compared to males $(p<0.001)$. Sleep latency score found to be significantly higher in females compared to males during COVID-19 $(p<0.001)$. In addition, sleep latency score significantly increased during the COVID-19 pandemic in females compared to males $(p<0.001)$. Sleep disturbance score found to be significantly higher in females compared to males during COVID-19 ( $\mathrm{p}<0.001)$. Daytime dysfunction score found to be significantly higher in females compared to males during COVID-19 ( $p=0.002)$. Similarly, daytime dysfunction score was significantly higher in females compared to males before COVID-19 ( $p=0.013)$.

Table 1. Demographic and psychological results

\begin{tabular}{|c|c|c|c|}
\hline & \multicolumn{2}{|c|}{ Gender } & \multirow[b]{2}{*}{ p-value } \\
\hline & Male $(n=171)$ & Female $(n=463)$ & \\
\hline Age (years) & $20.41 \pm 1.94$ & $20.13 \pm 1.86$ & 0.092 \\
\hline Chronic disease (yes) & $4(2.34 \%)$ & $35(7.56 \%)$ & $0.015^{*}$ \\
\hline \multicolumn{4}{|l|}{$\begin{array}{l}\text { How psychologically } \\
\text { affected you are due } \\
\text { to COVID-19 }\end{array}$} \\
\hline Not at all & $33(19.30 \%)$ & $15(3.24 \%)$ & \multirow[t]{5}{*}{$<0.001^{*}$} \\
\hline Slightly & $61(35.67 \%)$ & $114(24.62 \%)$ & \\
\hline Moderately & $46(26.90 \%)$ & $181(39.09 \%)$ & \\
\hline Considerably & $19(11.11 \%)$ & $96(20.73 \%)$ & \\
\hline Extremely & $12(7.02 \%)$ & $57(12.31 \%)$ & \\
\hline Anxiety level & $4(1-7)$ & $5(4-8)$ & $<0.001^{*}$ \\
\hline
\end{tabular}

Descriptives are expressed as mean \pm standard deviation, median $\left(25^{\text {th }}\right.$ percentile $75^{\text {th }}$ percentile) and frequency (percent). "Statistically significant at $\mathrm{p}<0.05$.

International Physical Activity Questionnaires (IPAQ-SF): IPAQ-SF score expressed as metabolic equivalent minutes per week (MET-min/week) was used as a general indicator of physical activity. We summarized results in Table 3. We found that overall IPAQ-SF score significantly decreased during COVID-19 compared to before COVID-19 ( $p<0.00$, Figure 2-A). In addition, Vigorous physical activity, Intermediate physical activity, Walking Activity decreased significantly during COVID-19 compared to before COVID-19 ( $\mathrm{p}<0.001$, $\mathrm{p}=0.002, \mathrm{p}=0.018$ and $\mathrm{p}<0.001$ respectively). Furthermore, a significant increase in sitting time was observed among students during COVID-19 compared to before COVID-19 $(\mathrm{p}<0.001)$, which is one of the indications of sedentary behavior. We compared also IPAQ-SF score and its components between gender groups. Overall IPAQ-SF score found to be higher in males compared to females in the last 7 days, however this difference was not statistically significant $(\mathrm{p}=0.096)$. On the other hand, overall IPAQ-SF score was significantly higher in males compared to females before COVID-19 ( $p=0.002$, figure 2-B). Only, walking activity score was significantly higher in males compared to females during COVID-19 $(p<0.001)$. Moreover, it was observed that walking activity score dramatically decreased in females compared to males $(\mathrm{p}=0.021)$ during COVID-19.
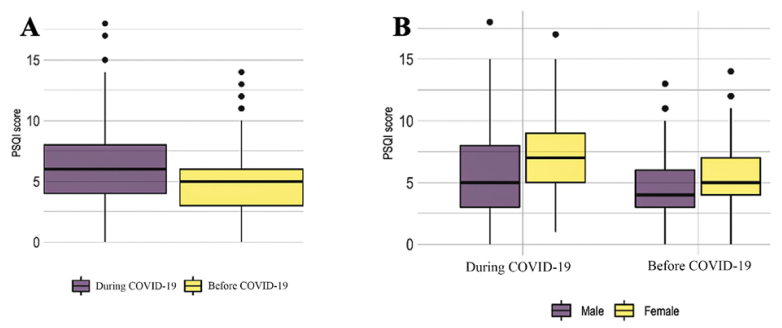

Figure 1. A) Overall PSQI score during and before COVID-19 B) Overall PSQI score during and before COVID-19 based on genders. PSQI, the Pittsburgh Sleep Quality Index.
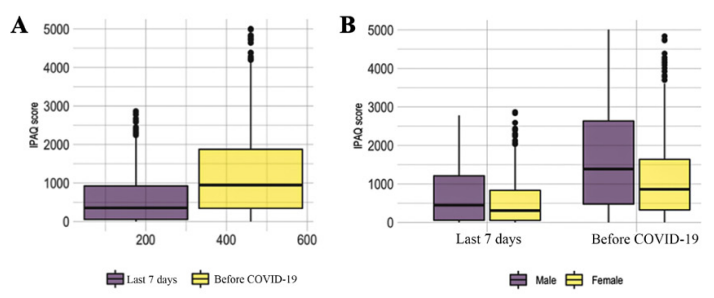

Figure 2. A) Overall IPAQ-SF score for last 7-day and before COVID-19. B) Overall IPAQ-SF score for last 7-day and before COVID-19 based on genders. IPAQ-SF, The International Physical Activity Questionnaire. 
Table 2. Comparison of PSQI score and its components during, before and between during and before the COVID-19 pandemic based on genders

\begin{tabular}{|c|c|c|c|c|c|c|}
\hline & \multirow[b]{2}{*}{ During COVID-19 } & \multirow[b]{2}{*}{ Before COVID-19 } & \multirow[b]{2}{*}{ p-value } & \multicolumn{3}{|c|}{ During COVID-19 } \\
\hline & & & & Male & Female & p-value \\
\hline Total & $6.48 \pm 3.04$ & $5.02 \pm 2.45$ & $<0.001^{*}$ & $\begin{array}{c}5.68 \pm 3.32 \\
\mathrm{n}=166\end{array}$ & $\begin{array}{c}6.83 \pm 2.90 \\
n=452\end{array}$ & $<0.001^{*}$ \\
\hline SSQ & $1.78 \pm 0.82$ & $1.14 \pm 0.66$ & $<0.001^{*}$ & $\begin{array}{c}1.54 \pm 0.84 \\
n=171\end{array}$ & $\begin{array}{c}1.87 \pm 0.79 \\
n=463\end{array}$ & $<0.001^{*}$ \\
\hline SL & $1.51 \pm 0.95$ & $1.00 \pm 0.80$ & $<0.001^{*}$ & $\begin{array}{c}1.24 \pm 1.62 \\
\mathrm{n}=171\end{array}$ & $\begin{array}{c}1.62 \pm 0.90 \\
\mathrm{n}=460\end{array}$ & $<0.001^{*}$ \\
\hline SDu & $0.36 \pm 0.78$ & $0.47 \pm 0.77$ & $0.003^{*}$ & $\begin{array}{c}0.46 \pm 0.83 \\
\mathrm{n}=171\end{array}$ & $\begin{array}{c}0.33 \pm 0.76 \\
\mathrm{n}=463\end{array}$ & 0.052 \\
\hline SE & $0.38 \pm 0.81$ & $0.54 \pm 0.93$ & $<0.001^{*}$ & $\begin{array}{c}0.41 \pm 0.82 \\
n=166\end{array}$ & $\begin{array}{c}0.38 \pm 0.81 \\
\mathrm{n}=455\end{array}$ & 0.669 \\
\hline SDi & $1.32 \pm 0.68$ & $1.04 \pm 0.52$ & $<0.001^{*}$ & $\begin{array}{c}1.10 \pm 0.66 \\
n=171\end{array}$ & $\begin{array}{c}1.40 \pm 0.67 \\
\mathrm{n}=463\end{array}$ & $<0.001^{*}$ \\
\hline USM & $0.09 \pm 0.47$ & $0.06 \pm 0.37$ & 0.077 & $\begin{array}{c}0.05 \pm 0.32 \\
\mathrm{n}=171\end{array}$ & $\begin{array}{c}0.11 \pm 0.52 \\
\mathrm{n}=463\end{array}$ & 0.164 \\
\hline DD & $1.04 \pm 0.98$ & $0.78 \pm 0.88$ & $<0.001^{*}$ & $\begin{array}{c}0.84 \pm 0.95 \\
\mathrm{n}=171\end{array}$ & $\begin{array}{c}1.12 \pm 0.98 \\
\mathrm{n}=463\end{array}$ & $0.002^{*}$ \\
\hline
\end{tabular}

Total, PSQI, score;SSQ, Subjective sleep quality; SL, Sleep latency; SDu, Sleep duration; SE, Sleep efficiency, SDi, Sleep disturbance; USM, Use of sleep medication; DD, Daytime dysfunction. Descriptives are expressed as mean \pm standard deviation. "Statistically significant at $\mathrm{p}<0.05$.

Table 3. Comparison of IPAQ-SF score and its components during, before and between during and before the COVID-19 pandemic based on genders

\begin{tabular}{|c|c|c|c|c|c|c|c|c|c|}
\hline & \multirow{2}{*}{ Last 7 days } & \multirow{2}{*}{$\begin{array}{c}\text { Before } \\
\text { COVID-19 }\end{array}$} & \multirow{2}{*}{ p-value } & \multicolumn{3}{|c|}{ Last 7 days } & \multicolumn{3}{|c|}{ Before COVID-19 } \\
\hline & & & & Male & Female & p-value & Male & Female & p-value \\
\hline Total & $317.50(45-862)$ & $\begin{array}{c}900.75 \\
(327.38-1710.50)\end{array}$ & $<0.001^{*}$ & $\begin{array}{c}448.50 \\
(51.75-1218.25) \\
n=141\end{array}$ & $\begin{array}{c}308.10 \\
(52.50-834) \\
n=439\end{array}$ & 0.096 & $\begin{array}{c}1387.50 \\
(474-2651.50) \\
n=145\end{array}$ & $\begin{array}{c}860.75 \\
(324.5-1642.5) \\
n=436\end{array}$ & $0.002^{*}$ \\
\hline VPA & $\begin{array}{c}1120(720- \\
1920)\end{array}$ & $\begin{array}{c}1440 \\
(720-2880)\end{array}$ & $0.002^{*}$ & $\begin{array}{c}1680 \\
(640-2400) \\
n=46\end{array}$ & $\begin{array}{c}1120 \\
(720-1600) \\
n=67\end{array}$ & 0.084 & $\begin{array}{c}1920 \\
(680-2880) \\
n=69\end{array}$ & $\begin{array}{c}1120 \\
(720-2400) \\
n=80\end{array}$ & 0.087 \\
\hline MPA & $360(180-640)$ & $\begin{array}{c}420 \\
(180-800)\end{array}$ & $0.018^{*}$ & $\begin{array}{c}480 \\
(171-780) \\
n=48\end{array}$ & $\begin{array}{c}360 \\
(240-600) \\
n=139\end{array}$ & 0.418 & $\begin{array}{c}600 \\
(224-1200) \\
n=69\end{array}$ & $\begin{array}{c}480 \\
(240-720) \\
n=155\end{array}$ & 0.065 \\
\hline WA & $396(148.5-594)$ & $\begin{array}{c}693 \\
(462-1386)\end{array}$ & $<0.001^{*}$ & $\begin{array}{c}445.50 \\
(198-792) \\
n=101\end{array}$ & $\begin{array}{c}297 \\
(132-495) \\
n=284\end{array}$ & $<0.001^{*}$ & $\begin{array}{c}742.5 \\
(462-1386) \\
n=115\end{array}$ & $\begin{array}{c}693 \\
(396-1386) \\
n=364\end{array}$ & 0.331 \\
\hline ST & $\begin{array}{c}12 \\
(7.5-16.5)\end{array}$ & $\begin{array}{c}7.5 \\
(4.5-10.5)\end{array}$ & $<0.001^{*}$ & $\begin{array}{c}12 \\
(7.5-15) \\
n=148\end{array}$ & $\begin{array}{c}12 \\
(8.3-18) \\
n=413\end{array}$ & 0.288 & $\begin{array}{c}7.5 \\
(4.5-10.5) \\
n=152\end{array}$ & $\begin{array}{c}7.5 \\
(4.5-10.5) \\
n=403\end{array}$ & 0.848 \\
\hline
\end{tabular}

Total, IPAQ-SF score ( $\mathrm{n}=546)$; VPA, Vigorous PA ( $\mathrm{n}=70)$; MPA, Moderate PA ( $\mathrm{n}=121)$; WA, Walking Activity (n=343); SA, Sitting time, min. $(\mathrm{n}=545)$. Descriptives are expressed as median $\left(25^{\text {th }}\right.$ percentile $-75^{\text {th }}$ percentile). ${ }^{*}$ Statistically significant at $p<0.05$. 


\section{DISCUSSION}

The present study was planned to investigate the changes in the sleep quality and physical activity habits of Trakya University Health Services Vocational School students during the COVID-19 pandemic. The most important findings of the study show that the lockdown applied within the scope of measures to combat the COVID-19 pandemic have caused negative effects on the sleeping and physical activity habits of university students in Turkey. This study collected data on demographics, sleep quality, physical activity and sedentary behavior habits. In this section, we discuss the limitations of our study, present the interpretations of the main findings, and share our recommendations for future policies and practices.

Adequate sleep and proper rest are considered among the main factors that improve physiological health and academic success in university students. Sleep deprivation is known to increase daytime sleepiness and inattentive behavior $(16,17)$. The advances in technology and the widespread use of smartphones have led to technology addiction among young adults. This increase is known to affect the quality and duration of sleep in students who keep their smartphones or computers nearby at bedtime (18, 19). Artificial lights, including those emitted by television screens, mobile phones and computers, suppress melatonin secretion, causing delayed sleeping hours $(20,21)$. Sleep disturbance and resulting outcomes during the day have negative effects on daily activities of the individual, and also represent an obstacle for an overall healthy lifestyle (22-24). These studies show that a considerable portion of university students experienced sleep disturbance even before the COVID-19 pandemic. The results of the present study showed that the restrictions and lockdown implemented due to the pandemic increased sleep disturbance among students.

With the restrictions introduced during the pandemic, students started spending more time at home, which led to sleeping at later hours as well as spending more time on smartphones, computers, video games, etc. at bedtime (25). Sleep quality appears to have deteriorated due to these unfavorable habits during the pandemic. In this study, we observed negative effects of the COVID-19 pandemic on subjective sleep quality, sleep duration, efficiency and effectiveness of the participating students. Foreign studies conducted during the COVID-19 pandemic support our findings $(25,26)$. However, when we compared the two genders in terms of the PSQI score, subjective sleep quality, sleep duration and daytime dysfunction, we found a greater effect in females compared to males. When the anxiety levels were compared, higher levels of anxiety were noted in females. Taken together, these findings suggest that the disturbed sleep quality reported by female students may be related to the increased level of anxiety in this group.

Habits of sleeping late and using the bed for purposes other than sleeping (eating, computer games, use of digital media, etc.) can lead to significant problems in the long term. Measures to be taken for such behavior may prevent further problems. Changing the habit of sleeping late at night is the most important measure in this context. In order to achieve this, one may keep record of when they go to sleep and wake up. Soothing activities may be planned for the 30 minutes before going to sleep, avoiding the use of technological devices in bed and at bedtime. By planning daytime activities, the individual can limit the time they remain inactive during the day. Using programs and applications developed for this purpose is another method to use time efficiently and increase overall motivation.

Physical activity and exercise have undisputed positive effects on non-communicable diseases $(27,28)$. Unfortunately, modern lifestyle encourages individuals to be physically inactive and leads to sedentary behavior. Such negative behavior is further exacerbated by quarantine measures, lockdown and curfews, which aim to reduce the spread of the COVID-19 virus.

The results of the present study show that all participants have experienced a significant decrease in their physical activity during the COVID-19 pandemic compared to the pre-pandemic period, with an increased duration of physical inactivity. It has been previously predicted that the COVID19-related restrictions would reduce physical activity (29). The measures taken and restrictions introduced in Turkey as well as in other countries due to the pandemic have radically changed daily habits of students, leading to an unfavorable impact on physical activity levels in particular. All participants in the study had a significant decrease in their IPAQ-SF scores and a significant increase in physical inactivity compared to the pre-pandemic period. Mean sitting time, which was 7.5 (4.5-10.5) hours/day before the COVID-19 pandemic, increased up to 12 (7.5-16.5) hours/day during the pandemic. A similar increase in sitting time was also observed in a study conducted with medical faculty students in Italy. Increased sitting times of up to 10 [8-12] hours were reported, even in participants with higher physical activity levels (25). University students 
are at risk of sedentary behavior and low levels of physical activity in the long-term due to distance education practices (30). Low levels of physical activity not only deprive the individual of the positive effects of exercise, but also represent an open invitation to several health conditions and diseases. Physical inactivity is recognized as a major health problem worldwide. "Low fitness level" has been determined as the leading factor increasing the risk of allcause mortality. Currently, we may not be aware of the harmful effects of physical inactivity; however, when these curfews and lockdowns are lifted and our lives return to the normal routine, especially university students may be at an increased risk of several potential disorders associated with prolonged physical inactivity (e.g. obesity, atherosclerosis, hypertension, type II diabetes, osteoporosis, heart failure, skeletal muscle atrophy, respiratory system diseases, reduced gastrointestinal motility, etc.).

Previous epidemiological studies have demonstrated that high levels of physical activity and exercise can mitigate the harmful effects of sedentary behavior $(25,31)$. Following the current recommendations concerning physical activity can be a good lifestyle modification for students with low activity levels $(27,32)$. Adopting behavioral patterns to shorten daily sitting time (e.g. standing when attending online classes instead of sitting or walking when making phone calls, etc.) would also be very useful for such students (33). One should bear in mind that there are exercise models that contribute to improving physiological health and thus quality of life in all age groups and in all kinds of health problems. Low-to-medium intensity, high-volume resistance exercise that can be easily practiced in home setting is known to have positive effects, especially when combined with a $15-25 \%$ reduction in daily energy intake. This combined regimen appears to be ideal to maintain neuromuscular, metabolic, and cardiovascular health.

The findings of this study should be interpreted considering several limitations. First, determining the quality of sleep and physical activity based on students' self-reports is less reliable than device-based measurements and may have caused these parameters to be under - or overestimated. Second, the IPAQ-SF questionnaire does not distinguish prolonged from intermittent sedentary time.

\section{CONCLUSION}

University students tend to sleep late at night, adopt sedentary behavior, and have low physical activity levels.
Curfews and lockdowns introduced due to the COVID-19 pandemic may worsen this tendency. The results of the present study show that the sleep quality and physical activity levels of students from Trakya University Vocational School have been negatively affected during the COVID-19 pandemic. Sleep latency score and subjective sleep quality found to be significantly higher in females compared to males during the COVID-19 pandemic $(p<0.001, p=0.005$, respectively). Our data will help raise awareness to improve sleep quality, increase physical activity, and shorten sitting time among university students. The data obtained in this study will contribute to the literature for the near future, which seems uncertain for the time being. Public health training programs and awareness training for schools aimed at increasing sleep quality and physical activity can be organized to improve these parameters.

\section{Ethics Statement}

Trakya University granted ethics approval for the study (TUTF-BAEK 2020/209). Written informed consent was obtained from all participants for publishing of any potentially identifiable images or data included in this article. Our online survey was conducted between 01-20 June 2020 when a lockdown was imposed on individuals under the age of 20 years. Participants were asked to answer a "yes-no question" to confirm their willingness to participate in the study on a voluntary basis. Once a positive answer was given to the question, participants were asked to complete the form that contained the sleep quality and physical activity scales.

\section{Highlights key points}

- Among the health services vocational school students participating in the study, females appeared to be psychologically affected by the COVID-19 pandemic to a further extent compared to males.

- A decrease was observed in the sleep quality of all participating students during the restrictions. The decline was higher in females compared to males.

- Walking activities of the students decreased while their sitting time increased during the restrictions. Weight gains were observed in $72 \%$ of the participants.

- Encouraging the use of mobile applications with social networking features and wearable technologies that aid in increasing physical activity and improving sleep 
quality may increase motivation by raising awareness among students.

\section{REFERENCES}

1. Organization WH. Novel Coronavirus.(2019-nCoV) technical guidance: laboratory guidance. Geneva: WHO Available via https://www.who.int/emergencies/diseases/ novel-coronavirus-2019/technical-guidance/laboratoryguidance Accessed. 2020;3.

2. Martínez-Lezaun I, Santamaría-Vázquez M, Del Líbano M. Influence of Confinement by COVID-19 on the Quality of Sleep and the Interests of University Students. Nature and Science of Sleep. 2020;12:1075.

3. Herian M, Desimone J. Examining Psychosocial Wellbeing and Performance in Isolated, Confined, and Extreme Environments Final Report. NASA/TM-2015; 2014.

4. Wright Jr KP, McHill AW, Birks BR, Griffin BR, Rusterholz T, Chinoy ED. Entrainment of the human circadian clock to the natural light-dark cycle. Current Biology. 2013;23(16):15548.

5. Aysan E, Karaköse S, Zaybak A, İsmailoğlu EG. Üniversite öğrencilerinde uyku kalitesi ve etkileyen faktörler. Dokuz Eylül Üniversitesi Hemşirelik Fakültesi Elektronik Dergisi. 2014;7(3):193-8.

6. Altena E, Baglioni C, Espie CA, Ellis J, Gavriloff D, Holzinger B, et al. Dealing with sleep problems during home confinement due to the COVID-19 outbreak: Practical recommendations from a task force of the European CBT-I Academy. Journal of Sleep Research. 2020:e13052.

7. Önder I, Masal E, Demirhan E, Horzum MB, Besoluk S. Psychometric Properties of Sleep Quality Scale and Sleep Variables Questionnaire in Turkish Student Sample. International Journal of Psychology and Educational Studies. 2016;3(3):9-21.

8. Dewald JF, Meijer AM, Oort FJ, Kerkhof GA, Bögels SM. The influence of sleep quality, sleep duration and sleepiness on school performance in children and adolescents: A metaanalytic review. Sleep medicine reviews. 2010;14(3):179-89.

9. Meijer AM. Chronic sleep reduction, functioning at school and school achievement in preadolescents. Journal of sleep research. 2008;17(4):395-405.

10. Li G, Fan Y, Lai Y, Han T, Li Z, Zhou P, et al. Coronavirus infections and immune responses. Journal of medical virology. 2020;92(4):424-32.

11. Jurak G, Morrison SA, Leskošek B, Kovač M, Hadžić V, Vodičar J, et al. Physical activity recommendations during the COVID-19 virus outbreak. Journal of Sport and Health Science. 2020.

12. Rodríguez MÁ, Crespo I, Olmedillas H. Exercising in times of COVID-19: what do experts recommend doing within four walls? Revista Espanola De Cardiologia (English Ed). 2020.

13. Buysse DJ, Reynolds III CF, Monk TH, Berman SR, Kupfer DJ. The Pittsburgh Sleep Quality Index: a new instrument for psychiatric practice and research. Psychiatry research. 1989;28(2):193-213.
14. Agargun M. Pittsburgh uyku kalitesi indeksinin gecerligi ve guvenirligi. Turk Psikiyatri Dergisi. 1996;7:107-15.

15. Committee IR. Guidelines for data processing and analysis of the International Physical Activity Questionnaire (IPAQ)short and long forms. http://Www ipaq ki se/scoring pdf. 2005.

16. Hauser SL, Josephson SA. Harrison's neurology in clinical medicine: McGraw-Hill Medical; 2010.

17. Lund HG, Reider BD, Whiting AB, Prichard JR. Sleep patterns and predictors of disturbed sleep in a large population of college students. Journal of adolescent health. 2010;46(2):124-32.

18. Mohammadbeigi A, Absari R, Valizadeh F, Saadati M, Sharifimoghadam S, Ahmadi A, et al. Sleep quality in medical students; the impact of over-use of mobile cellphone and social networks. Journal of research in health sciences. 2016;16(1):46.

19. Koulouglioti C, Cole R, Kitzman H. Inadequate sleep and unintentional injuries in young children. Public Health Nursing. 2008;25(2):106-14.

20. Bartel KA, Gradisar M, Williamson P. Protective and risk factors for adolescent sleep: a meta-analytic review. Sleep medicine reviews. 2015;21:72-85.

21. Wu X, Tao S, Zhang Y, Zhang S, Tao F. Low physical activity and high screen time can increase the risks of mental health problems and poor sleep quality among Chinese college students. PloS one. 2015;10(3):e0119607.

22. Orsal O, Orsal O, Alparslan GB, Unsal A. Evaluation of the relation between quality of sleep and anxiety among university students. HealthMED. 2012;6(7):2244-55.

23. Lovato N, Gradisar M. A meta-analysis and model of the relationship between sleep and depression in adolescents: recommendations for future research and clinical practice. Sleep medicine reviews. 2014;18(6):521-9.

24. Kline CE, Irish LA, Krafty RT, Sternfeld B, Kravitz HM, Buysse DJ, et al. Consistently high sports/exercise activity is associated with better sleep quality, continuity and depth in midlife women: the SWAN sleep study. Sleep. 2013;36(9):1279-88.

25. Luciano F, Cenacchi V, Vegro V, Pavei G. COVID-19 lockdown: Physical activity, sedentary behaviour and sleep in Italian medicine students. European Journal of Sport Science. 2020:1-10.

26. Maher JP, Hevel DJ, Reifsteck EJ, Drollette ES. Physical activity is positively associated with college students' positive affect regardless of stressful life events during the COVID-19 pandemic. Psychology of sport and exercise. 2020;52:101826.

27. Woods J, Hutchinson NT, Powers SK, Roberts WO, GomezCabrera MC, Radak Z, et al. The COVID-19 pandemic and physical activity. Elsevier; 2020.

28. Anderson E, Durstine JL. Physical activity, exercise, and chronic diseases: A brief review. Sports Medicine and Health Science. 2019;1(1):3-10.

29. Narici M, De Vito G, Franchi M, Paoli A, Moro T, Marcolin $\mathrm{G}$, et al. Impact of sedentarism due to the COVID-19 home confinement on neuromuscular, cardiovascular and metabolic 
health: Physiological and pathophysiological implications and recommendations for physical and nutritional countermeasures. European journal of sport science. 2020:122.

30. Castro O, Bennie J, Vergeer I, Bosselut G, Biddle SJ. How sedentary are university students? A systematic review and meta-analysis. Prevention Science. 2020;21(3):332-43.

31. Ekelund U, Steene-Johannessen J, Brown WJ, Fagerland MW, Owen N, Powell KE, et al. Does physical activity attenuate, or even eliminate, the detrimental association of sitting time with mortality? A harmonised meta-analysis of data from more than 1 million men and women. The Lancet. 2016;388(10051):1302-10.

32. World Health Organization t. Global recommendations on physical activity for health: World Health Organization; 2010.

33. Stamatakis E, Ekelund U, Ding D, Hamer M, Bauman AE, Lee I-M. Is the time right for quantitative public health guidelines on sitting? A narrative review of sedentary behaviour research paradigms and findings. British Journal of Sports Medicine. 2019;53(6):377-82. 